\title{
The Anthropological Witness of Celibacy
}

\section{Las enseñanzas antropológicas del celibato}

\section{Carter H. GRIFFIN}

St. John Paul II Seminary

Washington, DC. USA

ID ORCID 0000-0003-1341-2648

cartergriffin@praesidio.org

Abstract: This essay endeavors to demonstrate that celibacy «for the sake of the Kingdom» conveys important lessons for human flourishing. Celibacy is an anthropological witness to the possibility and conditions of faithful human love, the nobility as well as the limits of marriage, and the vocation of every Christian man to fatherhood in the order of grace. In the contemporary climate there is a great deal of anthropological confusion regarding the human person, including human love, marriage, and parenthood. As a result, these three lessons taught by apostolic celibacy are perhaps more urgently needed than ever before.

Keywords: Celibacy, Anthropology, Love, Marriage, Fatherhood.
Resumen: Este ensayo trata de mostrar que el celibato «por el Reino de los Cielos» transmite lecciones importantes sobre el florecimiento humano. El celibato es un testimonio antropológico de la posibilidad y las condiciones del amor humano fiel, de la nobleza y de los límites del matrimonio, y de la vocación de todo cristiano a la paternidad en el orden de la gracia. En el ambiente contemporáneo hay una gran confusión antropológica con respecto a la persona humana, que afecta a la comprensión del amor humano, del matrimonio y de la paternidad. En este sentido, estas tres lecciones enseñadas por el celibato apostólico son, quizás, más necesarias que nunca.

Palabras clave: Celibato, Antropología, Amor, Matrimonio, Paternidad. 


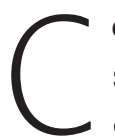
elibacy, to many, is seen as a denial of human nature. This may in fact seem evident to those who are skeptical of the Church's high estimation of the celibate life. It is said to oppose natural sexual desires, to oppose the goods and joys of marriage and children, and therefore to oppose human maturity and growth. Even those who support and admire apostolic celibacy may quietly fear that it depreciates full human development. They may see its very sacrifice of marriage and children as proof that it is simply a gift of grace, without claim or pretension to human flourishing. The purpose of this essay is to situate celibacy in another arena, that of its anthropological witness. It contends that celibacy, lived well, is conducive to human happiness and that it testifies to important human truths which are sorely needed today. Certainly celibacy «for the sake of the Kingdom» involves a weighty sacrifice and is a charism from God that can be lived well only with His grace. Moreover, its rationale is primarily to be found in theological motives that are eschatological, ecclesial, Christological, and pastoral. This essay will aspire to add to these motives its anthropological richness and witness, affirming that celibacy offers the world incomparable lessons about the nature of human love, marriage, and parenthood. By extension, it anticipates some of the human and cultural fallout should the general requirement for celibacy, particularly priestly celibacy, be abrogated or weakened.

\section{Celibacy Reveals the Path to Love}

As in every age, there is today a tremendous yearning for love. One of the greatest calamities of the so-called «sexual revolution», however, has been an approach to love which attempts to answer that yearning in superficial and harmful ways. In the minds of many, «love» has been reduced to a sentiment that is most intensely realized in sexual expression. The nobility and goodness of the body and sexual love have, as a consequence, been devalued by the very movement that promised to overcome, as is said, the moralistic excesses of the past. Pope Benedict observed that «Eros, reduced to pure "sex", has become a commodity, a mere "thing" to be bought and sold, or rather, man himself becomes a commodity. This is hardly man's great "yes" to the body» ${ }^{1}$. Celibacy, it will be argued, is a visible witness to the beauty of human love as well as an embodied lesson in protecting and fostering that love.

${ }^{1}$ Pope Benedict XVI, «Encyclical Letter Deus Caritas Est (2005)», n. 5. 
To begin, it would be difficult to exaggerate the repercussions of the sexual revolution. Its impact on marriages with permissive divorce laws and the prevalence of contraception, on the unborn with the social and legal acceptance of abortion, on children who live with the consequences of single parenthood and broken families, on those victimized by the spread of internet pornography, and on young people who are implicitly (and often explicitly) encouraged to experiment sexually before - or without the intention of - marriage, have all taken a toll on our social fabric and have damaged countless lives and families ${ }^{2}$. Thirty years ago Professor Allan Bloom, surveying the immediate wake of this social transformation, contended that there «are some who are men and women at the age of sixteen, who have nothing more to learn about the erotic. They are adult in the sense that they will no longer change very much. They may become competent specialists, but they are flatsouled. The world is for them what it presents itself to the senses to be; it is unadorned by imagination and devoid of ideals. This flat soul is what the sexual wisdom of our time conspires to make universal» ${ }^{3}$. Ironically, it is love itself, he argues, that is the last victim of this misdirected search for love. «Perhaps young people do not say "I love you"», he writes, «because they are honest. They do not experience love - too familiar with sex to confuse it with love, too preoccupied with their own fates to be victimized by love's mad selfforgetting, the last of the genuine fanaticisms» ${ }^{4}$.

Since celibacy is the relinquishing of marriage and physical sexual expression, it might be imagined to have little to say in a discussion about human love. Undeniably, celibacy has been defended at times in a way that depreciates human sexuality. Nevertheless, the tradition has never entirely lost sight of the fundamental reason for celibacy given by Christ, that it is embraced «for the sake of the Kingdom of Heaven» ${ }^{5}$. Celibacy in this light is a po-

\footnotetext{
2 See Eberstadt, M., Adam and Eve After the Pill: Paradoxes of the Sexual Revolution, San Francisco: Ignatius Press, 2013. Eberstadt points out that the most vulnerable members of the society, such as children and unborn babies, suffer disproportionately the effects of the sexual revolution. «This resolute refusal to recognize that the revolution falls heaviest on the youngest and most vulnerable shoulders - beginning with the fetus and proceeding up through children and adolescents - is perhaps the most vivid example of the denial surrounding the fallout of the sexual revolution. In no other realm of human life do ordinary Americans seem so indifferent to the particular suffering of the smallest and weakest» (29).

3 Bloom, A., The Closing of the American Mind, New York: Simon and Schuster, 1987, 134.

${ }^{4}$ Bloom, A., The Closing of the American Mind, 122.

${ }^{5}$ Mt 19:12.
} 
sitive choice of love, indeed a way of living sexual maturity, and it offers a profoundly important counterbalance to the false wisdom of the sexual revolution. Allen Vigneron writes «celibacy can be a form of sexual fulfillment, because in celibacy we can give ourselves generously, fully, sacrificially to another in a way that is certainly life-generating $»^{6}$. Indeed the notion that celibacy is emotionally or psychologically inhibiting simply defies the «testimony offered by the great majority of priests, who live their celibacy with internal freedom, rich evangelical motivation, spiritual depth, and in a panorama of strong and joyful fidelity to their vocation and mission» ${ }^{7}$.

Far from sanctioning a kind of contented bachelorhood, intentional celibacy for the Kingdom is a reminder that true love is found not primarily in sexual activity but in the life of charity which unites us to God and to one another and which alone satisfies the deep yearning for love and meaning that the sexual revolution promised to deliver ${ }^{8}$. Blessed Paul VI writes that «the free choice of sacred celibacy has always been considered by the Church "as a symbol of, and stimulus to, charity": it signifies a love without reservations; it stimulates to a charity which is open to all. In a life so completely dedicated and motivated, who can see the sign of spiritual narrowness or self-seeking, and not see rather that celibacy is and ought to be a rare and very meaningful example of a life motivated by love, by which man expresses his own unique greatness?» ${ }^{9}$ Thus a «priest who lives a contented, enthusiastic celibate life challenges some strong cultural prejudices without so much as raising his voice», writes George Aschenbrenner ${ }^{10}$. His celibacy «announces that the paramount value in human life of a profoundly satisfying joy does not chiefly result from mature genital sexual activity, but from the self-gift of any loving sacrifice. These faith statements about the meaning of human life fly directly

\footnotetext{
${ }^{6}$ Vigneron, A., «Can Celibacy Be Defended?», Crisis 18, n. 11 (December 2000) 43.

7 Ibid. See also Pope Benedict XVI, «Encyclical Letter Caritas in Veritate (2009)», n. 5; Pope Paul VI, «Encyclical Letter Sacerdotalis Caelibatus (1967)», nn. 13 and 53; POPE PIUS XII, «Encyclical Letter Sacra Virginitas (1954)», n. 33; and GroesCHeL, B. J., The Courage to be Chaste, New York: Paulist Press, 1985, 16. Though this discussion will emphasize the celibacy of priests, much of it applies equally to consecrated virgins and laymen who embrace apostolic celibacy.

${ }^{8}$ On the dangers of celibate «bachelorhood» see Aschenbrenner, G. A., Quickening the Fire in Our Midst, Chicago: Loyola Press, 2002, 124.

9 Sacerdotalis Caelibatus, n. 24. Also see DubaY, Th., ... and You Are Christ's: The Charism of Virginity and the Celibate Life, San Francisco: Ignatius Press, 1987, 75 and Aschenbrenner, G. A., Quickening the Fire in Our Midst, 117.

10 Aschenbrenner, G. A., Quickening the Fire in Our Midst, 125-126.
} 
in the face of our culture's sexually fixated self-indulgence» ${ }^{11}$. Well lived, celibacy is a compelling witness to the true nature of human love for those whom philosophical and theological arguments and even pastoral exhortations may leave unmoved ${ }^{12}$.

Indeed, it is only in this context of charity that genuine sexual fulfillment can be found. Celibacy shows men and women, regardless of their vocation, that the sexual drive can and must be directed to true human flourishing. It reveals to the world how to release love from the shackles of sexual idolatry and points the way to a life that corrects the exaggerations of the sexual revolution and gradually heals its wounds. Celibacy is not a neutering of those who embrace it for the sake of the Kingdom; rather it is a channeling of their sexual energies towards higher goods. In the case of the celibate person, as in all people, this requires a certain discipline of life, choices to protect the gift of sexual intimacy, and an interior life to open up the currents of grace which alone make the Christian virtue of chastity possible and beautiful.

On a practical level, the Church offers perennial wisdom to those who have embraced celibacy for the Kingdom in order to safeguard the gift they have made. These include prayer, the sacraments, a heartfelt devotion to the Blessed Virgin Mary, and ascetical practices which help to foster the disciplined life needed to live celibacy well ${ }^{13}$. Especially in an age that considers perfect continence impossible, the Second Vatican Council teaches, «priests should all the more humbly and steadfastly pray with the Church for that grace of fidelity, which is never denied those who seek it, and use all the supernatural and natural aids available» ${ }^{14}$. This same advice, and these same practices, can and should be pursued by every Christian, both married and unmarried, aspiring to live chastity well. They have demonstrated in countless lives that regular encounters with grace make the life of chastity possible and

${ }^{11}$ Ibid. Patricia Snow remarks that we «live in a world where Freudian ideas still hold sway, including the idea that religion is a sublimation of sex. The celibate, by his example, proposes a truth exactly opposite: that every other love, every lesser love, is a sublimated form of the love of God». (SNOW, P., «Dismantling the Cross», First Things, n. 252 [April 2015] 41).

12 See Dubay, Th., ... and You Are Christ's: The Charism of Virginity and the Celibate Life, 142-143 and Galot, J., «The Priesthood and Celibacy», Review for Religious 24 (1965) 949 and BoHR, D., The Diocesan Priest, Collegeville: Liturgical Press, 2009, 146-147.

13 See Pope John Paul II, «Post-Synodal Apostolic Exhortation Pastores Dabo Vobis (1992)», n. 29 and Sacerdotalis Caelibatus nn. 30 and 55.

14 Second Vatican Council, «Decree on the Ministry and Life of Priests Presbyterorum Ordinis (1965)», n. 16. 
joyful, which is one of the most important lessons taught by celibacy today. In contrast, it is the reckless «wisdom» of our times that denies the need for grace and the steady application of self-discipline in order to experience the freedom of chastity. Shakespeare wrote that «the strongest oaths are but straw to the fire in the blood» because he understood what in our naiveté is overlooked today, that all our indulgence of sex and our stretching of sexual boundaries have not changed the simple power of the sexual urge and its capacity both to unite and to destroy. «An intoxicated and undisciplined eros», Pope Benedict wrote, «is not an ascent into "ecstasy" towards the Divine, but a fall, a degradation of man. Evidently, eros needs to be disciplined and purified if it is to provide not just fleeting pleasure, but a certain foretaste of the pinnacle of our existence, of that beatitude for which our whole being yearns ${ }^{15}$.

In addition to this witness of chastity and the means to safeguard it, by forgoing all physical sexual expression celibates offer other irreplaceable lessons to the men and women of our time. To those who are unmarried, including those who for a variety of reasons will never marry - reasons which seem to be ever more common today - celibate men and women show that an unmarried life can nevertheless be meaningful, joyful, and healthy. Even for those who are married, there will be seasons when it is advisable or even necessary to abstain from sexual activity. Married couples may prayerfully discern that they are to abstain periodically in Natural Family Planning with a goal to spacing out births. Or it may be that couples are physically separated for a time by professional demands or the exigencies of war. Some couples may decide, as St. Paul taught, to refrain from sexual activity for a period to devote themselves more fully to prayer ${ }^{16}$. It is lived celibacy that most powerfully demonstrates the wisdom and the feasibility of living the demands of chastity in these and similar circumstances.

Celibacy, then, reveals to a world weary with failed sexual experimentation that there is a truer, nobler, and healthier road to radical love and sexual fulfillment. Those who embrace celibacy for sake of the Kingdom remind their

15 Deus Caritas Est, n. 4. Also see Balthasar, H. U. von, «The Meaning of Celibacy», Communio: International Catholic Review 3, n. 4 (Winter 1976) 327.

${ }^{16}$ See 1 Cor 7:5. Paul Claudel writes that «the soul and the spirit are just as real and strong and demanding as the flesh - they are much more so! - and that if we allow the flesh everything it asks for, this is to the detriment of other joys, other marvelous realms, which will remain closed to us forever». (Claudel's correspondence is cited by Cantalamessa, R., Virginity: A Positive Approach to Celibacy for the Sake of the Kingdom of Heaven, New York: Society of Saint Paul, 1995, 10). 
contemporaries that all love, including sexual love, realizes its potential only when it finds its terminus in divine love, and finds its protection only when guarded by virtue. The path to chastity is admittedly hard at times, but it is the only path to genuine joy. As Pope Benedict once observed to priests, «May Christianity give us joy, just as love gives joy. But love is always also a renunciation of self. The Lord himself has given us the formula of what love is: those who lose themselves find themselves; those who spare or save themselves are lost. It is always "Exodus", hence, painful. True joy is something different from pleasure; joy grows and continues to mature in suffering, in communion with the cross of Christ. It is here alone that the true joy of faith is born» ${ }^{17}$.

\section{Celibacy Reveals the Dignity of MarRiage}

As celibacy, in forgoing sexual activity, is paradoxically a powerful witness to the beauty of human love, so too, in forgoing marriage, is it paradoxically a witness to the dignity and beauty of conjugal life. In order to understand this claim, it is helpful first to remember that celibacy only makes sense in the context of a community. Precisely because not everyone can be celibate, even from a purely natural perspective, the celibate vocation presumes a prior community of which he is a member. Since, moreover, apostolic celibacy is «for the sake of the Kingdom», it is ordered to an augmentation of that Kingdom by fostering communion, orienting the celibate person towards the service of others. Thus priestly celibacy «is not only an eschatological sign; it also has a great social meaning, in the present life, for the service of the People of God. Through his celibacy, the priest becomes the "man for others", in a different way from the man who, by binding himself in conjugal union with a woman, also becomes, as husband and father, a man "for others", especially in the radius of his own family» ${ }^{18}$. We know from the beginning of the Book of Genesis that man is made for communion with others, to be in relationship with others $^{19}$. The celibate is a living proof that all people, regardless of marital sta-

17 Pope Benedict XVI, «Address of His Holiness Benedict XVI to Diocesan Clergy of Aosta (July 25, 2005)».

${ }^{18}$ Pope John Paul II, «Letter of His Holiness John Paul II to All the Priests on the Occasion of Holy Thursday 1979», n. 8. Referring this ordering to communio in the ecclesial context, see CraWford, D., «Christian Community and the States of Life: A Reflection on the Anthropological Significance of Virginity and Marriage», Communio: International Catholic Review 29, n. 2 (Summer 2002) 363.

${ }^{19}$ Gen 2:18. 
tus, are called to deep and meaningful relationships and to full membership in the human and ecclesial family.

More specifically, by sacrificing the goods of marriage so highly esteemed by the Church, the celibate priest reveals their beauty and dignity. The «sacrifice of the human love experienced by most men in family life and given up by the priest for the love of Christ», Blessed Paul VI wrote, «is really a singular tribute paid to that great love. For it is universally recognized that man has always offered to God that which is worthy of both the giver and the receiver» ${ }^{20}$. Raniero Cantalamessa makes the point even more strongly. He observes that celibacy has «no meaning apart from the simultaneous affirmation of marriage. If marriage were something negative, renouncing it would not be a free choice but a duty $\gg^{21}$. Saint Paul goes so far as to say that Christ's celibacy sets the standard by which all love is measured. «Husbands, love your wives, as Christ loved the church and gave himself up for her $\gg^{22}$. Thus far from diminishing the Church's reverence for the marital vocation, by «virtue of this witness, virginity or celibacy keeps alive in the Church a consciousness of the mystery of marriage and defends it from any reduction and impoverishment ${ }^{23}$.

At the same time, celibacy offers an important correction to an appraisal of marriage which sets it in false competition with higher goods. Paul Claudel wisely observed that «God promises by his creatures but only fulfills by himself $\gg^{24}$. The great good of marriage finds its highest expression not in arrogating to itself honor due to God alone, but in drawing the couple ever closer to the heavenly archetype of divine love. Celibacy reminds married people «that marriage is holy, beautiful, and redeemed by Christ. It is the image of the betrothal of Christ to the Church, but... it is not everything. It is a reality that is linked to this world and therefore transitory. It no longer exists where death

20 Sacerdotalis Caelibatus, n. 50. Also Pope John Paul II, «Apostolic Exhortation Familiaris Consortio (1981)», n. 16: «Virginity or celibacy for the sake of the Kingdom of God not only does not contradict the dignity of marriage but presupposes it and confirms it. Marriage and virginity or celibacy are two ways of expressing and living the one mystery of the covenant of God with His people. When marriage is not esteemed, neither can consecrated virginity or celibacy exist; when human sexuality is not regarded as a great value given by the Creator, the renunciation of it for the sake of the Kingdom of Heaven loses its meaning».

${ }^{21}$ Cantalamessa, R., «Dimensions of Priestly Celibacy», in Cavadini, J. C. (ed.), The Charism of Priestly Celibacy: Biblical, Theological, and Pastoral Reflections, Notre Dame: Ave Maria Press, 2012, 8.

22 Eph 5:25.

${ }^{23}$ Familiaris Consortio, n. 16.

${ }^{24}$ Cited in SNOw, P., «Dismantling the Cross», 38. 
no longer exists. When, as Jesus said, it will no longer be possible to die, there will be no more need to marry» ${ }^{25}$.

Far from diminishing conjugal life, this wise corrective to exaggerated views of marriage frees it from unhealthy and unrealistic expectations. By reminding married people of the primacy of divine love, it reminds them as well that «God has made us for Himself and that therefore our hearts will always be "unsatisfied", until they rest in him. It is a reminder, too, that marriage and the family cannot be turned into an idol to which everything and everyone is sacrificed, a kind of absolute in life», Cantalamessa writes. «And since the first casualty of such undue absolutization is marriage itself, which is crushed by these disproportionate expectations which it will never be able to satisfy, this is why I say that virginity comes to the aid of married people themselves. It liberates marriage and each of the partners from the unbearable weight of having to be "everything" for the other, of taking the place of God» ${ }^{26}$.

Forgetting its relative value, that it is a means and not an end, that it is a vocation and not a right, has led to much of the current confusion regarding marriage. On the one hand marriage seems to be considered the highest good of life and one impossible to justly withhold from anyone, including those whose relationship renders it impossible to unite in marriage due to prior marital bonds, circumstances of life, physical or mental capacity, and now even the very sexes of the couple ${ }^{27}$. On the other hand, this fixation on marriage is contradicted by a comparatively low estimation of the permanence of marriage, of its essential ordering to the generation of children, and of its foundational importance for social cohesion and cultural formation. The Christian who embraces celibacy for the Kingdom offers clarity in the midst of confusion through a living testimony to both the dignity and beauty of marriage as well as its relative value compared to higher goods.

Moreover, the witness of celibacy, in addition to affirming the dignity of marriage and its ordering to higher goods, is a vibrant encouragement and support to those who have embraced the marital state, in several ways. Firstly, it is an encouragement to the life of chastity, noted above, which married couples must live in a way suited to their vocation, and which is as essential in protecting their mutual love as it is in protecting the hearts of the unmarried. Se-

${ }^{25}$ Cantalamessa, R., Virginity, 7-8.

26 Cantalamessa, R., Virginity, 8.

27 See SNOW, P., «Dismantling the Cross», 40. 
condly, since celibate love does not engage in physical sexual expression, it depends upon other ways to show love in friendship and affection, befitting different degrees and kinds of relationships. Celibacy can thus be a reminder to married couples that theirs is the highest of human friendships and that they, too, can and should express their love in a wide variety of ways, resisting the temptation to a kind of affective «sloth» which gradually reduces expressions of love to physical intimacy alone ${ }^{28}$. Thirdly, the nature of priestly celibacy is such that, far from distancing himself from the struggles of married persons, it confers on him a greater capacity to understand and help those in the conjugal state. Though of course he does not have first-hand experience of some marital problems, if the priest were married «he would also run the risk of becoming excessively engrossed in the problems of his own family. He would not be able to be open enough to the various problems of other couples» ${ }^{29}$. Furthermore the «affective and mental freedom stemming from celibacy enables the priest to sympathize in greater depth with all human situations and to bring to people the help which God offers $»^{30}$. Fourthly, and most importantly, in their fidelity those who embrace celibacy offer a lived encouragement to married couples to persevere in their own demanding vocation. Saint John Paul II taught that Christian couples «have the right to expect from celibate persons a good example and a witness of fidelity to their vocation until death. Just as fidelity at times becomes difficult for married people and requires sacrifice, mortification and self-denial, the same can happen to celibate persons, and their fidelity, even in the trials that may occur, should strengthen the fidelity of married couples» ${ }^{31}$.

Far from diminishing the dignity of marriage, then, or setting itself in competition with it, celibacy is perhaps the most important witness in the world today to the beauty and nobility of conjugal life, not only in highlighting the grandeur of the goods that celibacy sacrifices, but also in protecting marriage from disproportionate expectations which weigh it down and overwhelm it. Thus celibacy not only upholds the dignity of marriage but also points the way to marital happiness and reinforces and encourages those who

28 This «spectrum» of intimacy is especially important for a couple that chooses to engage in $\mathrm{Na}-$ tural Family Planning, since NFP demands periods of abstinence, often precisely when sexual desire is most intense.

29 Galot, J., Theology of the Priesthood, San Francisco: Ignatius Press, 1985, 245-246.

${ }^{30}$ Ibid.

${ }^{31}$ Familaris Consortio, n. 16. Also see Pastores Dabo Vobis, n. 50 and Sacerdotalis Caelibatus, n. 57. 
have embraced the vocation. Pope Benedict alluded to these lessons of celibacy at the conclusion of the Year for Priests in 2010. He pointed out that celibacy has nothing to do with simply «avoiding marriage» which can be «based on a will to live only for oneself, of not accepting any definitive tie, to have the life of every moment in full autonomy, to decide at any time what to do, what to take from life; and therefore a "no" to the bond, a "no" to definitiveness, to have life for oneself alone». Celibacy, he insisted, «is the opposite of this "no", of this autonomy that accepts no obligations, which will not enter into a bond. It is the definitive "yes" that supposes, confirms the definitive "yes" of marriage» ${ }^{32}$. It has been justly stated, in an expression highly paradoxical to many today, that «Catholic celibacy is the backbone of Catholic marriage». The arguments briefly outlined in this section have endeavored to provide some justification for that paradox.

\section{Celibacy Reveals the Priority of Supernatural Fatherhood}

A third way in which celibacy provides a powerful anthropological witness today is in its ordering to supernatural fatherhood ${ }^{33}$. Celibacy is a reminder to priest and layman alike that their highest generative calling is in the order of grace. Before pointing out the anthropological witness of celibacy in this regard, it is important first to understand what is meant by supernatural fatherhood and how celibacy, especially priestly celibacy, renders a man more capable of exercising it and witnessing to it.

Jesus instructed his disciples to «call no man on earth your father, for you have one Father, who is in heaven ${ }^{34}$. These words, often used to argue for the unscriptural foundations of priestly fatherhood, are in fact the clearest witness that human beings - including celibate priests - have a share in God's own fatherhood. Since Jesus' admonition obviously cannot deny the attribution of physical fatherhood to men, it must point to the truth that all human father-

32 Pope Benedict XVI, «Dialogue of the Holy Father Benedict XVI with Priests, Conclusion of the Year for Priests (June 10, 2010)».

33 Portions of the following section are drawn from Griffin, C. H., «The Fatherhood of the Celibate Priest», in CavadinI, J. C. (ed.), The Charism of Priestly Celibacy: Biblical, Theological, and Pastoral Reflections, Notre Dame: Ave Maria Press, 2012, 109-124. A more extensive treatment may also be found in the author's doctoral dissertation: GrifFIN, C. H., Supernatural Fatherhood through Priestly Celibacy, Fulfillment in Masculinity: A Thomistic Study, Rome: Pontifical University of the Holy Cross, 2011.

${ }^{34}$ Mt 23:9. 
hood is grounded in God's Paternity of the Eternal Son, the ontological origin of all paternity in heaven and on earth, as St. Paul tells the Ephesians ${ }^{35}$. When God made Adam and Eve and inscribed into their being the call to be fruitful, he was inscribing a part of himself into humanity. Human generation is not simply the biological mechanism for physical reproduction; it is sharing in the very life of God through the cooperative act of pro-creation. Thus human fatherhood is found most immediately and most clearly in the communion of human persons in which a man and a woman generate a third ${ }^{36}$. God enters into that union and creates something that did not exist before, something totally beyond their natural capacity to generate: an immortal, rational, human soul. Wondrous as that is, however, human fatherhood goes further. The procreation of a child is ordered not just to its bare existence, but to its true human development; not just to its biological generation, but to its natural perfection. In contrast to biological fatherhood, one might call this natural fatherhood, through which a man provides for his child, guides and teaches his son or daughter, and protects his child from harm.

The task of the human father goes still further. Biological and natural fatherhood are themselves ordered to the third and highest degree of human paternity: fatherhood in the order of grace - that is, supernatural fatherhood. A human child, after all, is not born simply for temporal life, not born only to enjoy the goods of this world, but also - and even more so - to enjoy the imperishable goods of heaven. The child is born for eternal life. The highest

35 «For this reason I bow my knees before the Father, from whom every father in heaven and on earth is named» (Eph 3:14-15). There is further (though veiled) evidence from the New Testament that Jesus intends an analogous link between God's fatherhood and human fatherhood. Jean Galot points out that Jesus' decision to use the word $A b b a$, normally employed in a familial setting, itself stresses the similitude between a human father and His divine Father (GALOT, J., Abba Father, New York: Alba House, 1992, 67). In St. Luke's Gospel, Jesus makes a direct comparison between human fatherhood and divine Fatherhood when He asks, «What father among you, if his son asks for a fish, will instead of a fish give him a serpent; or if he asks for an egg, will give him a scorpion? If you then, who are evil, know how to give good gifts to your children, how much more will the heavenly Father give the Holy Spirit to those who ask him!» (Lk 11:11-13).

36 Strictly speaking, the analogue to God's fatherhood is human fatherhood since it is precisely God as Father who was revealed by Christ. The specific features of divine paternity are more clearly inscribed in human fatherhood than in motherhood, not only biologically and psychologically but ontologically: the father begets, and the mother receives. Through his seed the father is the «principle» of the child in a way that bears a certain resemblance to Adam as the principle of the human race and God as the principle of being. Nevertheless, with respect to divine generation itself, both mothers and fathers contribute an equal role in human generation, and hence equally serve as secondary causes. In this sense, much of what follows can also be applied to supernatural motherhood. 
duty of fathers, then - and of mothers as well - is to be generators of their children's supernatural lives through prayer, sacrifice, teaching of the faith, setting an example of Christian discipleship, bringing them to the sacraments, forming them in virtue, and leading them to Christ.

With this brief schema of human generation in mind, it is evident that those who are celibate for the sake of the Kingdom dedicate their lives to this third and highest degree of paternity. In the case of priests, their exercise of supernatural paternity might be summarized through the triple munera of priesthood. In the munus sanctificandi, for instance, the priest generates supernatural life by administering the sacraments. He bestows that life in baptism, confirms and strengthens it in confirmation, heals it in confession and anointing, and directs it to the common good through Holy Orders and by witnessing matrimony ${ }^{37}$. Above all, however, the priest exercises his fatherhood in celebrating the Holy Eucharist, the source of supernatural life in the Church and the food through which her children are nourished.

In the munus docendi, as teacher and preacher, the priest prepares his people to receive the sacraments, especially the Holy Eucharist, and helps to plant the seed of God's Word in their hearts. Saint Thomas Aquinas taught that priests «father with their voice» ${ }^{38}$ and St. Paul gives us a powerful example of this supernatural paternity in his first letter to the Corinthians: «Even if you should have countless guides to Christ», Paul writes, «yet you do not have many fathers, for I became your father in Christ Jesus through the Gospel» ${ }^{39}$.

In the munus regendi, the priest fulfills the very fatherly functions of guiding his people into truth and wisdom and leading them towards God. He shows them the way to happiness. No one more than the priest engages people in so many ways, so deeply touching their souls in moments of joy and sorrow, revealing to them God's love and mercy, with repercussions that last not only a lifetime but for eternity. In addition, every father must protect his children, and no one more than the priest. Like Moses, he is called to stand in the breach, placing himself, as a shepherd, between his people and any danger that may threaten them, defending them from the ravages of sin, from doctrinal

${ }^{37}$ Pope Pius XI enumerates a similar sacramental comparison of supernatural to natural life in POPE PIUs XI, «Encyclical Letter Ad Catholici Sacerdotii (1935)», nn. 17-18.

38 St. Thomas Aquinas, Commentary on the First Epistle to the Corinthians, Chapter 4-3. Elsewhere St. Thomas explicitly calls «the work of preaching» the means by which the «fruit of souls is procreated» (Quodlibet VII, Q. 7, A. 2 co).

391 Cor $4: 15$. 
error, from interior confusion, from threats to their natural and spiritual wellbeing even, if necessary, at the cost of his own life.

The priest's celibacy is a particularly powerful sign of this supernatural fatherhood and a privileged way of living it. Blessed Paul VI wrote that the priest's celibacy «inculcates in him, as a sign of a higher and greater fatherhood, a generosity and refinement of heart which offer a superlative enrichment» ${ }^{40}$. In the mind of Pope Francis, celibacy is so closely aligned to fatherhood that the two cannot be separated in a healthy life. When a man does not have the desire for fatherhood, he said, «something is missing in this man. Something is wrong. All of us, to exist, to become complete, in order to be mature, we need to feel the joy of fatherhood: even those of us who are celibate» ${ }^{41}$.

In the munus sanctificandi, for instance, priestly celibacy is particularly apt for the celebration of the Holy Eucharist. The life-giving sacrifice of Jesus made present in the Holy Eucharist finds an echo in the generative, personal sacrifice of the priest's celibacy. The Holy Sacrifice gives shape and meaning to the priest's own self-oblation and inasmuch as celibacy is part of that selfgift, it becomes an important stimulus to his paternal generativity ${ }^{42}$. Moreover, the celibate love of Jesus for each person is powerfully reflected in the priest's own celibate love and fidelity. Standing in the place of Christ the Head, his celibacy dramatically symbolizes the spousal love of the virginal Christ for His Bride, the Church, in the very liturgical action that renews that nuptial relationship ${ }^{43}$.

In the munus docendi, Aquinas teaches that celibacy is ordered to contemplation ${ }^{44}$, and it is through contemplation that a priest's preaching is nourished and made supernaturally fruitful. Every priest has had the experience of preaching from the overflow of his prayer and the impact that such preaching can have on others. If St. Thomas is right that celibacy can promote a contemplative life, it follows that it also contributes to the priest's «fathering with

40 Sacerdotalis Caelibatus, n. 56.

41 Pope Francis, «Morning Meditation in the Chapel of the Domus Sanctae Marthae, The Foy of Fatherhood (June 26, 2013)».

42 See Sacerdotalis Caelibatus, nn. 29-30. Also see Galot, J., «The Priesthood and Celibacy», 945.

43 McGovern, Th., «The Spousal Dimension of the Priesthood», The National Catholic Bioethics Quarterly 3, n. 1 (Spring 2003) 96-97.

44 St. Thomas Aquinas, Summa Theologiae II-II, Q. 152, A.2 co. As noted earlier, St. Paul instructed married couples that they could abstain from sexual relations for a period in order to «devote yourselves to prayer» (1 Cor 7:5), itself an implicit reference to the ordering of celibacy to the work of contemplation. 
his voice». Moreover, not only is celibacy more favorable to contemplation, its more deliberate dependence on grace is a stimulus to prayer for the celibate priest, as the Church has pointed out ${ }^{45}$, which itself nourishes his preaching and helps make it fruitful.

It is in the munus regendi, however, that the priest's celibacy makes the clearest contribution to his supernatural paternity. Celibacy offers the priest a wider scope of pastoral activity and facilitates his provision of the sacraments, intercessory prayer, and active works of charity. The Second Vatican Council describes celibacy as «a sign and stimulus for pastoral charity and a source of spiritual fruitfulness in the world» and renders the priest «better fitted for a broader acceptance of fatherhood in Christ ${ }^{46}$. It opens his life to the needs of all his children, dilating his heart to embrace all his brothers and sisters. It is a visible witness to the dignity of human sexuality, as noted earlier, and an encouragement to human love that is healthy, faithful, and chaste. It prepares him to sacrifice on behalf of others, training him for the spiritual battle and even for martyrdom in defense of the faith and of his people.

Celibacy, then, is ordered not simply to an imitation of Christ in his choice of celibacy. It is ordered to the priest's own ministry, to his fruitfulness in the order of grace, that is to say, to his fatherhood. This is a positive and compelling vision of celibacy in defiance of skeptical perspectives which dismiss celibacy as a regrettable relic of the past, stunting the human maturity of the priest and perhaps the cause of dangerous sexual aberrations. When celibacy is understood to enhance the priest's very identity as a father in the order of grace, as coloring every fiber of his being and his priestly ministry, then celibacy becomes a rich source of human satisfaction, personal joy, and priestly fruitfulness. Celibacy is no longer viewed as a burden to carry, but as a gift to treasure. As Pope Pius XII wrote in his Apostolic Exhortation Menti Nostrae, by the law of celibacy «the priest, so far from losing the gift and duties of fatherhood, rather increases them immeasurably, for, although he does not beget progeny for this passing life of earth, he begets children for that life which is heavenly and eternal».

The celibacy of the priest is, then, an impetus and a means of living his own supernatural fatherhood; and it reveals a still deeper truth. It is a reminder and a witness that every biological father, indeed every man, is called to

45 Presbyterorum Ordinis, n. 16.
46 Ibid. 
exercise fatherhood in the order of grace, in fact that such is his highest vocation. Married or unmarried, every Christian is to generate supernatural life in others through his prayer, sacrifice, works of mercy, teaching, and protection of others, particularly the most vulnerable. Even if he is not a biological father, each is nonetheless called to live the fatherhood of grace. The celibate priest, through his very celibacy and his supernatural paternity, is a living witness to that important fact.

\section{CONCLUSION}

The purpose of this essay has been to identify important anthropological truths to which celibacy, particularly priestly celibacy, is ordered. In part, these reflections are made in light of perennial questions posed about celibacy, though today these discussions contain a new twist. Not only are the theological and pastoral motives of celibacy under scrutiny today; also at question are the very feasibility of celibacy, the kind of a life it fosters, and the anthropological signals it sends to the Church and the rest of the world. This essay has focused on these latter questions. In effect, what would the well-informed «man on the street» learn from the celibate witness of a priest? He would learn a great deal about matters that are as provocative, as vital to his wellbeing, and as poorly understood as any today. He would learn from celibacy the possibility of radical love, the virtuous means to obtain and preserve it, and the joy that flows from it. In an age of confusion, he would learn from celibacy, through its very sacrifice, of the nobility of human marriage, and be reminded that marriage, if it is to be happy and fulfilling, cannot satisfy a depth of yearning which only God can answer. He would learn from celibacy that every person is called to give life, whether biologically or not, and since the highest form of life is supernatural, it is the glory and joy of every man to be called to be an instrument of life-giving grace to those around him, that is, to be a father in the supernatural order. Truly these three lessons are more urgently needed today than ever before, in the midst of great anthropological confusion and division. They are lessons powerfully taught by the practice of celibacy, particularly among parish priests where most Catholics encounter it, because they are lessons uniquely, most visibly, and most beautifully taught by those who have embraced celibacy «for the sake of the Kingdom of Heaven». 


\section{Bibliography}

Aquinas, Th., Commentary on the First Epistle to the Corinthians.

Aquinas, Th., Quodlibet VII.

Aquinas, Th., Summa Theologiae.

Aschenbrenner, G. A., Quickening the Fire in Our Midst, Chicago: Loyola Press, 2002.

Benedict XVI, Pope, Address of His Holiness Benedict XVI to Diocesan Clergy of Aosta, July 25, 2005.

Benedict XVI, Pope, Dialogue of the Holy Father Benedict XVI with Priests, Conclusion of the Year for Priests, June 10, 2010.

BeNEDICT XVI, Pope, Encyclical Letter Caritas in Veritate, 2009.

Benedict XVI, Pope, Encyclical Letter Deus Caritas Est, 2005.

Bloom, A., The Closing of the American Mind, New York: Simon and Schuster, 1987.

Bohr, D., The Diocesan Priest, Collegeville: Liturgical Press, 2009.

Cantalamessa, R., «Dimensions of Priestly Celibacy», in Cavadini, J. C. (ed.), The Charism of Priestly Celibacy: Biblical, Theological, and Pastoral Reflections, Notre Dame: Ave Maria Press, 2012, 5-26.

Cantalamessa, R., Virginity: A Positive Approach to Celibacy for the Sake of the Kingdom of Heaven, New York: Society of Saint Paul, 1995.

Crawford, D., «Christian Community and the States of Life: A Reflection on the Anthropological Significance of Virginity and Marriage», Communio: International Catholic Review 29, n. 2 (Summer 2002) 337-365.

Dubay, Th., ... and You Are Christ's: The Charism of Virginity and the Celibate Life, San Francisco: Ignatius Press, 1987.

Eberstadt, M., Adam and Eve After the Pill: Paradoxes of the Sexual Revolution, San Francisco: Ignatius Press, 2013.

Francis, POPE, Morning Meditation in the Chapel of the Domus Sanctae Marthae: The foy of Fatherhood, June 26, 2013.

Galot, J., Abba Father, New York: Alba House, 1992.

Galot, J., «The Priesthood and Celibacy», Review for Religious 24 (1965) 930-956.

Galot, J., Theology of the Priesthood, San Francisco: Ignatius Press, 1985.

Griffin, C. H., «The Fatherhood of the Celibate Priest», in CavadinI, J. C. (ed.), The Charism of Priestly Celibacy: Biblical, Theological, and Pastoral Reflections, Notre Dame: Ave Maria Press, 2012, 109-124. 
GRIFFIN, C. H., Supernatural Fatherhood through Priestly Celibacy, Fulfillment in Masculinity: A Thomistic Study, Rome: Pontifical University of the Holy Cross, 2011.

Groeschel, B. J., The Courage to be Chaste, New York: Paulist Press, 1985.

JAKI, S. L., Theology of Priestly Celibacy, Front Royal: Christendom Press, 1997.

John Paul II, Pope, Apostolic Exhortation Familiaris Consortio, 1981.

John Paul II, Pope, Letter of His Holiness Fohn Paul II to All the Priests on the Occasion of Holy Thursday 1979.

John Paul II, Pope, Post-Synodal Apostolic Exhortation Pastores Dabo Vobis, 1992.

McGovern, Th., Priestly Celibacy Today, Princeton: Scepter Press, 1998.

McGovern, Th., «The Spousal Dimension of the Priesthood», The National Catholic Bioethics Quarterly 3, n. 1 (Spring 2003) 95-110.

Paul VI, PoPe, Encyclical Letter Sacerdotalis Caelibatus, 1967.

Pius XI, Pope, Encyclical Letter Ad Catholici Sacerdotii, 1935.

PIUs XII, Pope, Encyclical Letter Sacra Virginitas, 1954.

Second Vatican Council, Decree on the Ministry and Life of Priests Presbyterorum Ordinis (1965).

SNOW, P., «Dismantling the Cross», First Things n. 252 (April 2015) 33-42.

Vigneron, A., «Can Celibacy Be Defended?», Crisis 18, n. 11 (December 2000) 42-46.

Von Balthasar, H. U., «The Meaning of Celibacy», Communio: International Catholic Review 3, n. 4 (Winter 1976) 318-329. 